\title{
Production and Properties of a Soymilk-clotting Enzyme System from a Microorganism
}

\author{
Yang Won Park, Isao KusaKabe, Hideyuki Kobayashi \\ and Kazuo MuraKami \\ Institute of Applied Biochemistry, University of Tsukuba, \\ Sakura-mura, Niihari-gun, Ibaraki 305, Japan \\ Received May 7, 1985
}

\begin{abstract}
Some microorganisms, including some bacteria isolated from soil, were found to secrete an extracellular soymilk-clotting enzyme. Among them, strain No. K-295G-7 showed the highest soymilk-clotting activity and stability of the production of the soymilk-clotting enzyme. The enzyme system (culture filtrate) coagulated protein in soymilk, a curd being formed at $\mathrm{pH} 5.8 \sim 6.7$ and at $55 \sim 75^{\circ} \mathrm{C}$. The optimum temperature for the soymilk-clotting activity was $75^{\circ} \mathrm{C}$ and the enzyme system was stable at temperatures below $50^{\circ} \mathrm{C}$ down to $35^{\circ} \mathrm{C}$. About $80 \sim 100 \%$ of the original activity remained after $1 \mathrm{hr}$ at $\mathrm{pH} 5 \sim 7$ and $35^{\circ} \mathrm{C}$.
\end{abstract}

It has been recognized that soybeans are a food material with a high nutritive value because they contain good quality protein and a high percentage of essential fatty acids. For this reason, soy-beans have been extensively used as the raw material for traditional foods, such as "Tôfu" (bean curd), "Miso" (bean paste), "Shôyu" (soy sauce) and so on, since ancient times in Japan. In many countries, soybeans have also been regarded as one of the major important sources of protein for human beings. Soybeans, however, have a few shortcomings such as their beany flavor, ${ }^{1,2)}$ and water absorption and retention in the gel used for cheese-like foods. ${ }^{3}$ The simple elimination of these properties would be beneficial for the further utilization of soybean protein.

Several workers ${ }^{4 \sim 10)}$ have attempted to improve the functional properties of soybean protein by enzymatic, physical and chemical modifications. Lately, it has been reported that Bromelain, a plant protease, is capable of clotting the protein in soymilk, soymilk curd therby being formed. Fuke and Matsuoka ${ }^{3,4)}$ and Mohri and Matsushita ${ }^{5)}$ reported that soymilk, acid-precipitated soy-bean protein, and isolated 11S globulin were clotted by Bromelain. They also investigated the proper- ties of the curd and the clotting mechanism involved.

No report, however, has appeared on the efficiency of a microbial enzyme to clot soybean protein. This paper deals with the screening of organisms producing a soymilk-clotting enzyme, and the production and investigation of some properties of the enzyme.

\section{MATERIALS AND METHODS}

Soymilk. Soymilk, "Kibun Tônyu Muchôsei (pH 6.7)," was purchased from Kibun Co., Ltd. (Japan).

Isolation sources of microorganisms. Soil samples, collected from various districts of Japan, were the sources for isolation of microorganisms producing a soymilk-clotting enzyme.

Isolation of microorganisms producing a soymilk-clotting enzyme. The first screening was performed as follows: one drop of a soil suspension diluted 100- to 1,000-fold with sterilized water was spread on an agar plate containing medium A (Table I), followed by incubation at $30^{\circ} \mathrm{C}$ for 3 days. The colonies growing on the plate were picked up and maintained on Bennet agar slants ( $B$ in Table $I$ ) at ambient room temperature. About 300 colonies of bacteria and about 150 colonies of fungi were isolated from 300 soil samples by this method.

The second screening was performed as follows: about $10 \mathrm{ml}$ of the soymilk adjusted to $\mathrm{pH} 6.0$ with $1 \mathrm{M}$ potassium 
Table I. Medium Compositions (\%)

\begin{tabular}{cccccccccc}
\hline & Soymilk & Dextrose & N.Z. Amine & Peptone & Yeast ex. & Beef ex. & $\mathrm{KH}_{2} \mathrm{PO}_{4}$ & Agar & $\mathrm{pH}$ \\
\hline $\mathrm{A}$ & 5 & 0.2 & & 0.2 & 0.2 & & 0.2 & 1.3 & 6.1 \\
$\mathrm{~B}$ & & 1.0 & 0.2 & & 0.1 & 0.1 & 1.0 & 1.5 & 5.6 \\
$\mathrm{C}$ & 5 & 0.2 & & 0.2 & 0.2 & & 0.5 & & 6.1 \\
\hline
\end{tabular}
A: Composition of medium for 1 st screening.
B: Composition of medium for slants.
C: Composition of medium for enzyme production.

phosphate buffer ( $\mathrm{pH} 4.5$ ) was placed in a test tube with a cotton plug, and sterilized at $120 \mathrm{C}$ for $15 \mathrm{~min}$. One loop of each isolate from the first screening was inoculated into the soymilk, followed by incubation at $35 \mathrm{C}$ for 2 days. By this method, 70 bacterial isolates and 60 fungal isolates, which were observed to coagulate soymilk, were selected and maintained on agar slants ( $B$ in Table I).

The organisms were subjected to a third screening as follows: twenty-five $\mathrm{ml}$ of the medium for enzyme production ( $\mathrm{C}$ in Table $\mathrm{I}$ ) was placed in $100 \mathrm{ml}$ shaking flasks (Sakaguchi flasks). After sterilization at $120 \mathrm{C}$ for $15 \mathrm{~min}$, one loop of each isolate from the second screening was inoculated into the medium, followed by incubation at $35 \mathrm{C}$ for 3 days on a reciprocal shaker ( 125 oscillations per min). The resultant culture broth was centrifuged at $9,000 \times g$ for $20 \mathrm{~min}$ to remove insoluble materials including the cells. The supernatant liquid, thus obtained, was used as the enzyme solution (enzyme system). Three bacterial isolates designated as $\mathrm{W}-18 \mathrm{a}, \mathrm{W}-18 \mathrm{~b}$ and $\mathrm{K}$ 295G-7 showed relatively high soymilk-clotting activity.

Assay for soymilk-clotting activity. One half $\mathrm{ml}$ of the enzyme solution was added to $5 \mathrm{ml}$ of soymilk adjusted to $\mathrm{pH} 6.1$ with $1 \mathrm{~m}$ potassium phosphate buffer $(\mathrm{pH} 4.5)$, and the clotting activity was determined at $65 \mathrm{C}$ as described by Arima et al. ${ }^{11}$ The amount of enzyme that clotted $5 \mathrm{ml}$ of soymilk in $1 \mathrm{~min}$ under the above conditions was defined as 1 soymilk-clotting unit.

\section{RESULTS}

Evidence of soymilk coagulation by the enzyme system

One half $\mathrm{ml}$ of the enzyme solution was added to $5 \mathrm{ml}$ of soymilk adjusted to $\mathrm{pH} 6.1$ with $1 \mathrm{~m}$ potassium phosphate buffer ( $\mathrm{pH} 4.5$ ). After incubation at $65 \mathrm{C}$ for $5 \mathrm{~min}$, the resultant coagulum was centrifuged at $1,100 \times g$ for $5 \mathrm{~min}$.

Figure 1 shows that soymilk was coagulated by the enzyme system produced by the W-18a, W-18b and K-295G-7 strains, while no coagulation was observed either on the addition of

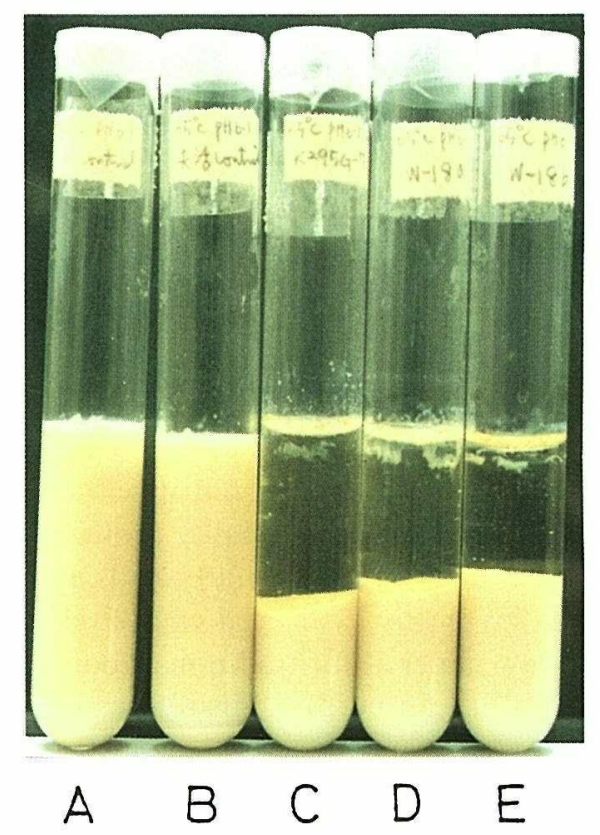

FIG. 1. Coagulation of Soy-milk by the Enzyme Reaction.

A, water; B, inactivated enzyme; C, K-295G-7; D, W18a; E, W-18b.

water (A in Fig. 1) or the enzyme system treated at $100 \mathrm{C}$ for $5 \mathrm{~min}$ (B in Fig. 1). These observations indicate that the soymilk-clotting was caused by the enzyme reaction. The coagula (Tôfu-like), which were obtained on enzyme treatment, were separated into curd and whey after centrifugation.

Soymilk-clotting enzyme production by $K$ $295 G-7$

In this work, we used K-295G-7 as a representative strain for further study of the soymilk-clotting enzyme, because the enzyme 
produced by this strain exhibited the highest activity and stability of production among the three strains. Three liters of the enzyme production medium ( $\mathrm{C}$ in Table $\mathrm{I}$ ), containing a small amount of Tôshiba silicone defoamer, was poured into a 5-liter Jar fermentor, followed by sterilization at $120^{\circ} \mathrm{C}$ for $15 \mathrm{~min}$ in an autoclave. The seed culture $(200 \mathrm{ml})$ of $\mathrm{K}$ -

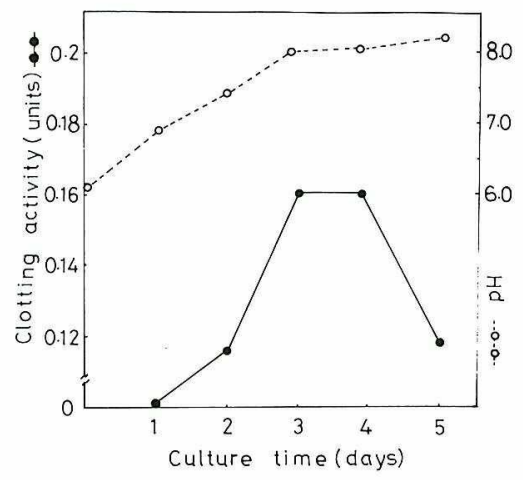

Fig. 2. Time Course of Cultivation.

-- $--\bigcirc--, p H ;-0-$, clotting activity.
295G-7, which had been grown in the same medium in $500 \mathrm{ml}$ shaking flasks at $35^{\circ} \mathrm{C}$ for 2 days on a reciprocal shaker, was inoculated into the fermentor. The cultivation was carried out at $35^{\circ} \mathrm{C}$ at an aeration rate of 1.5 liters $/ \mathrm{min}$ with agitation at $650 \mathrm{rpm}$. At suitable time intervals, a small amount of the culture broth was withdrawn and centrifuged, and then the enzyme activity in the supernatant was assayed. Figure 2 shows the time course of cultivation. The maximum soymilk-clotting activity, which was 0.16 units $/ \mathrm{ml}$, was observed at 3 to 4 days after the beginning of cultivation.

Effects of temperature and $p H$ on curd formation

In this experiment, an ammonium sulfate fraction was used as the enzyme solution. Ammonium sulfate was added to the supernatant obtained on cultivation of K-295G-7 to $80 \%$ saturation with the salt. The resultant



Fig. 3. Coagulation of Soy-milk by the Crude Enzyme from K-295G-7.

A: Effect of Temperature on Soymilk-clotting at pH 6.1. Reactions were carried out at various temperatures for $5 \mathrm{~min}$.

B: Effect of $\mathrm{pH}$ on Soymilk-clotting at $65^{\circ} \mathrm{C}$. Reactions were carried out at different $\mathrm{pHs}$ for $5 \mathrm{~min}$. 


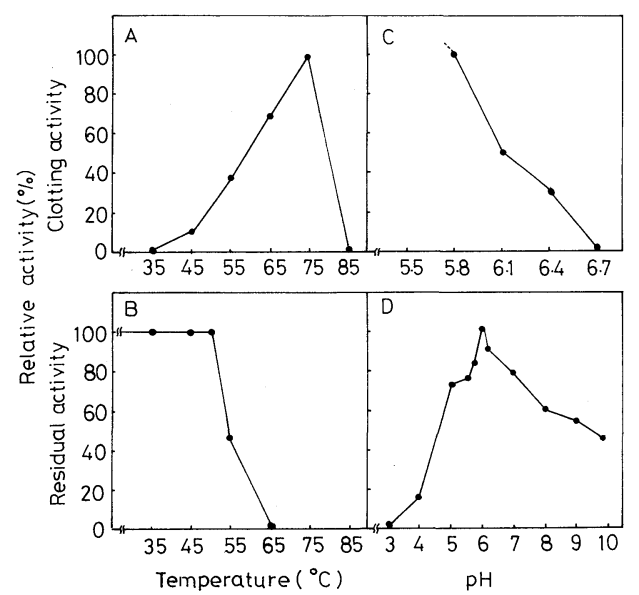

FIG. 4. Some Properties of the Soymilk-clotting Enzyme from a Microorganism (K-295G-7).

A: Effect of Temperature on Soymilk-clotting Activity. Reaction mixtures containing $5 \mathrm{ml}$ of soymilk, adjusted to $\mathrm{pH} 6.1$, and $0.5 \mathrm{ml}$ of enzyme solution were incubated at various temperatures for $30 \mathrm{~min}$.

B: Effect of $\mathrm{pH}$ on Soymilk-clotting Activity. Soymilkclotting activity was determined at different $\mathrm{pHs}$, ranging from 5.8 to 7.0 , under the conditions of $65^{\circ} \mathrm{C}$ for $30 \mathrm{~min}$. C: Effect of Temperature on Stability. The enzyme solution ( $\mathrm{pH}$ 6.1) was stood at various temperatures for $30 \mathrm{~min}$. Then the residual activity was determined.

D: Effect of $\mathrm{pH}$ on Stability. One half $\mathrm{ml}$ of the enzyme solution and $0.5 \mathrm{ml}$ of McIlvaine buffer were mixed and stood at $35^{\circ} \mathrm{C}$ for $1 \mathrm{hr}$. After adjustment to $\mathrm{pH} 6.1$, the residual activity was determined.

precipitate was collected by filtration on TôyôRoshi No. 2 filter paper and dissolved in a small amount of water. The enzyme solution, thus obtained, was dialyzed against a 20 -fold volume of $0.04 \mathrm{~m}$ potassium phosphate buffer $(\mathrm{pH}$ 6.1). In order to examine the effect of temperature on curd formation, reactions were carried out at various temperatures at $\mathrm{pH} 6.1$ for $5 \mathrm{~min}$ and the resultant coagula were centrifuged at $1,100 \times g$ for $5 \mathrm{~min}$. As shown in A in Fig. 3, a curd was clearly formed at $55^{\circ} \mathrm{C}$ and $65^{\circ} \mathrm{C}$, but not at $45^{\circ} \mathrm{C}$ or $75^{\circ} \mathrm{C}$. On the other hand, the effect of $\mathrm{pH}$ on curd formation was investigated at different $\mathrm{pHs}$ ranging from 5.8 to 7.0 under the conditions of $65^{\circ} \mathrm{C}$ for 5 min. B in Fig. 3 shows that after the enzyme reaction, the soymilk was easily separated into curd and whey at pHs 5.8, 6.1 and 6.4.
Properties of the enzyme from $K-295 G-7$

An ammonium sulfate fraction was also used as the enzyme solution in this experiment. The $\mathrm{pH}$ and temperature dependency profiles of the soymilk-clotting activity are shown in A and $\mathrm{B}$ in Fig. 4. The enzyme exhibited maximum activity at around $75^{\circ} \mathrm{C}$ at $\mathrm{pH} 6.1$, and no activity was seen at $35^{\circ} \mathrm{C}$ and $85^{\circ} \mathrm{C}$ (A in Fig. 4). On the other hand, the activity decreased as the $\mathrm{pH}$ increased from 5.8 to 6.7 (B in Fig. 4). However, the soymilk-clotting activity test could not be carried out below $\mathrm{pH}$ 5.8 because soymilk coagulated without the addition of the enzyme solution. The thermal and $\mathrm{pH}$-stabilities are illustrated in $\mathrm{C}$ and $\mathrm{D}$ in Fig. 4. The enzyme was stable at temperatures below $50^{\circ} \mathrm{C}$ down to $35^{\circ} \mathrm{C}$ when treated at $\mathrm{pH}$ 6.1 for $30 \mathrm{~min}$. However, treatment at $55^{\circ} \mathrm{C}$ under the same conditions resulted in the loss of $53 \%$ of the original activity. On the other hand, the enzyme solution retained soymilkclotting activity at $35^{\circ} \mathrm{C}$ for $1 \mathrm{hr}$ in McIlvaine buffer ranging from $\mathrm{pH} 3 \sim 10$. About $80 \sim 100 \%$ of the original activity remained after treatment in a $\mathrm{pH}$ range of $5 \sim 7$, while $47 \%$ of the activity remained even at $\mathrm{pH} 10.0$.

\section{DISCUSSION}

It was not known whether microorganisms secrete a soymilk-clotting enzyme. This is the first paper which deals with the efficient production of soymilk curd with the aid of a soymilk-clotting enzyme from a microorganism. The authors were able to isolate some bacteria capable of coagulating soymilk protein, from 300 soil samples. This suggests that microorganisms having such a property are widely distributed in nature.

It was obvious that the coagulation of protein in soymilk was due to the reaction caused by the enzyme from K-295G-7, because the phenomenon was observed at $\mathrm{pH} 6.1$ with an ammonium sulfate or acetone or ethanol fraction (data not shown), but not on heating the culture filtrate to $100^{\circ} \mathrm{C}$ for $5 \mathrm{~min}$ (Fig. 1). However, it was not clear whether the coagulation was due to a single enzyme action or the 
combined action of several enzymes. Further characterization of the enzyme system and the mechanism of coagulation would be interesting from enzymological viewpoints, and may be accomplished by investigating the properties of the purified enzyme. Work along these lines including the identification of K-295G-7 is now progress in our laboratory.

It is well known that soymilk curd is produced by means of isoelectric point precipitation and chemical coagulation due to divalent metals or glucono- $\delta$-lactone. Recently, it was reported that plant proteases, such as Bromelain and Ficin, ${ }^{3)}$ coagulate protein in soymilk, and the resulting curd has a soft and smooth texture. The curd made with the enzyme system from K-295G-7 also has a smooth texture, and a mild taste without any bitterness or a beany flavor. This result shows that the curd obtained through the enzymatic action can serve as a material for further development of food items, and the procedure may be widely applicable to food processing.

\section{REFERENCES}

1) S. Arai, O. Koyanagi and M. Fujimaki, Agric. Biol. Chem., 31, 868 (1967).

2) S. Arai, M. Noguchi, M. Kaji, H. Kato and M. Fujimaki, Agric. Biol. Chem., 34, 1420 (1970).

3) Y. Fuke and H. Matsuoka, Nippon Shokuhin Kôgyo Gakkaishi, 27, 275 (1980).

4) Y. Fuke and H. Matsuoka, J. Food Sci., 49, 312 (1984)

5) M. Mohri and S. Matsushita, J. Agric. Food Chem., 32, 486 (1984).

6) Y. Yamano, E. Miki and Y. Fukui, Nippon Shokuhin Kogyo Gakkaishi, 28, 131 (1981).

7) C. H. Lee and C. K. Rha, J. Food Sci., 43, 79 (1978).

8) K. Saio, I. Sato and T. Watanabe, J. Food Sci., 39, 777 (1974).

9) B. R. Suresh Chandra, A. G. Appu Rao and M. S. Narasinga Rao, J. Agric. Food Chem., 32, 1402 (1984).

10) S. Damodaran and John E. Kinsella, J. Agric. Food Chem., 30, 812 (1982).

11) K. Arima, S. Iwasaki and G. Tamura, Agric. Biol. Chem., 31, 540 (1967). 